7. Manian FA. Bloodstream infection with Oligella ureolytica, Candida krusei, and Bacteroides species in a patient with AIDS. Clin Infect Dis. 1993;17:290-1. http://dx.doi.org/10.1093/ clinids/17.2.290

8. Welch WD, Porschen RK, Luttrell B. Minimal inhibitory concentrations of 19 antimicrobial agents for 96 clinical isolates of group IVe bacteria. Antimicrob Agents Chemother. 1983;24:432-3. http://dx.doi.org/10.1128/AAC.24.3.432

9. Klinger JD, Thomassen MJ. Occurrence and antimicrobial susceptibility of gram-negative nonfermentative bacilli in cystic fibrosis patients. Diagn Microbiol Infect Dis. 1985;3:149-58. http://dx.doi.org/10.1016/0732-8893(85)90025-2

10. Winn WC, Allen SD, Janda WM, Koneman EW, Procop GW, Schreckenberger PC, Woods GL.The nonfermentative gramnegative bacilli. In: Koneman EW, editor. Koneman's color atlas and textbook of diagnostic microbiology. 6th ed. Washington (DC): Lippincott Williams \& Wilkins; 2005. p. 303-91.

Address for correspondence: Tristan Simmons, Philadelphia College of Osteopathic Medicine, 4170 City Ave, Philadelphia, PA 19131, USA; email: tristansi@pcom.edu

\title{
Estimating Ebola Treatment Needs, United States
}

\section{Gabriel Rainisch, ${ }^{1}$ Jason Asher, ${ }^{1}$ Dylan George, ${ }^{1}$ Matt Clay, Theresa L. Smith, Christine Kosmos, Manjunath Shankar, Michael L. Washington, Manoj Gambhir, Charisma Atkins, Richard Hatchett, Tim Lant, ${ }^{2}$ Martin I. Meltzer ${ }^{2}$}

Author affiliations: Centers for Disease Control and Prevention, Atlanta, Georgia, USA (G. Rainisch, T.L. Smith, K. Cosmos, M. Shankar, M. Washington, C. Atkins, M.I. Meltzer); Leidos, Reston, Virginia, USA (J. Asher, M. Clay); Biomedical Advanced Research and Development Authority, Washington, DC, USA (D. George, R. Hatchett, T. Lant); Monash University, Melbourne, Victoria, Australia (M. Gambhir)

DOI: http://dx.doi.org/10.3201/eid2107.150286

To the Editor: By December 31, 2014, the Ebola epidemic in West Africa had resulted in treatment of 10 Ebola case-patients in the United States; a maximum of 4 patients received treatment at any one time (1). Four of these 10 persons became clinically ill in the United States ( 2 infected outside the United States and 2 infected in the United States), and 6 were clinically ill persons medically evacuated from West Africa (online Technical Appendix 1 Table 6, http://wwwnc.cdc.gov/EID/article/21/7/15-0286Techapp1.pdf).

To plan for possible future cases in the United States, policy makers requested we produce a tool to estimate future numbers of Ebola case-patients needing treatment at

${ }^{1}$ These first authors contributed equally to this article.

${ }^{2}$ These senior authors contributed equally to this article. any one time in the United States. Gomes et al. previously estimated the potential size of outbreaks in the United States and other countries for 2 different dates in September 2014 (2). Another study considered the overall risk for exportation of Ebola from West Africa but did not estimate the number of potential cases in the United States at any one time (3).

We provide for practicing public health officials a spreadsheet-based tool, Beds for Ebola Disease (BED) (online Technical Appendix 2, http://wwwnc.cdc.gov/EID/ article/21/7/15-0286-Techapp2.xlsx) that can be used to estimate the number of Ebola patients expected to be treated simultaneously in the United States at any point in time. Users of BED can update estimates for changing conditions and improved quality of input data, such as incidence of disease. The BED tool extends the work of prior studies by dividing persons arriving from Liberia, Sierra Leone, and Guinea into the following 3 categories: 1) travelers who are not health care workers (HCWs), 2) HCWs, and 3) medical evacuees. This categorization helps public health officials assess the potential risk for Ebola virus infection in individual travelers and the subsequent need for postarrival monitoring (4).

We used the BED tool to calculate the estimated number of Ebola cases at any one time in the United States by multiplying the rate of new infections in the United States by length of stay (LOS) in hospital (Table). The rate of new infections is the sum of the rate of infected persons in the 3 listed categories who enter the United States from Liberia, Sierra Leone, or Guinea. For the first 2 categories of travelers, low and high estimates of Ebola-infected persons arriving in the United States are calculated by using low and high estimates of both the incidence of disease in the 3 countries and the number of arrivals per month (Table). Calculating the incidence among arriving HCWs required estimating the number of HCWs treating Ebola patients in West Africa (online Technical Appendix 1, Tables 2-4). For medical evacuations of persons already ill from Ebola, we calculated low and high estimates using unpublished data of such evacuations through the end of December 2014.

Although only 1 Ebola case has caused additional cases in the United States (7), we included the possibility that each Ebola case-patient who traveled into the United States would cause either 0 secondary cases (low estimate) or 2 secondary cases (high estimate) (Table). Such transmission might occur before a clinically ill traveler is hospitalized or between a patient and HCWs treating the patient (7). To account for the possibility that infected travelers may arrive in clusters, we assumed that persons requiring treatment would be distributed according to a Poisson probability distribution. Using this distribution enables us to calculate, using the BED tool, 95\% CIs 
Table. Calculated monthly rates of Ebola disease among persons arriving in the United States and additional secondary cases, 2014

\begin{tabular}{|c|c|c|c|c|c|c|c|}
\hline $\begin{array}{l}\text { Arriving } \\
\text { persons }\end{array}$ & & $\begin{array}{c}\text { Input 1: } \\
\text { infections/mo* }\end{array}$ & $\begin{array}{l}\text { Input 2: at-risk } \\
\text { population }\end{array}$ & $\begin{array}{c}\text { Input 3: US } \\
\text { arrival rate/mo† }\end{array}$ & $\begin{array}{c}\text { Output 1: } \\
\text { importations/mo } \neq\end{array}$ & $\begin{array}{l}\text { Output 4: additional } \\
\text { secondary cases } \S\end{array}$ & $\begin{array}{c}\text { Output 2: total } \\
\text { cases/mo }\end{array}$ \\
\hline \multirow[t]{2}{*}{ Non-HCW } & Low & 1 & 10,000 & 2,000 & 0.2 & 0 & 0.2 \\
\hline & High & 3 & 10,000 & 3,000 & 0.9 & 2 & 2.7 \\
\hline \multirow[t]{2}{*}{$\mathrm{HCW}$} & Low & 1 & 100 & 30 & 0.3 & 0 & 0.3 \\
\hline & High & 5 & 100 & 60 & 3.0 & 2 & 9.0 \\
\hline \multirow{2}{*}{$\begin{array}{l}\text { Medical } \\
\text { evacuations }\end{array}$} & Low & NA & NA & 1 & 1.0 & 0 & 1 \\
\hline & High & NA & NA & 3 & 3.0 & 0 & 3 \\
\hline
\end{tabular}

*Infections in travelers who are not HCWs were based on the monthly incidence identified in World Health Organization situation reports during JuneOctober 2014 (online Technical Appendix 1 Table 1) (5). The high value was the highest monthly incidence [September] rounded to the nearest whole number; the low value was set at $30 \%$ of the high value. Infections in HCWs were based on estimates of the number of HCWs in West Africa with and without Ebola virus infection at different times in the epidemic [online Technical Appendix 1 and Appendix 1 Tables 2-4]. HCW, health care worker; NA, not applicable.

tThe low estimate of US arrival rates for travelers who are not HCWs and both the low and high rates for HCWs were based on the count of screened airline passengers originating in Liberia, Sierra Leone, and Guinea in the month from mid-October through mid-November 2014 (Centers for Disease Control and Prevention [CDC], unpub. data). For the high US arrival rate for travelers who are not HCWs, we assumed a $50 \%$ increase over the low value $[3,000=2,000 \times 1.5]$ to approximate the arrival rate in 2013 , before the epidemic (3). Rates of HCW arrivals were based on travelers who identified themselves as having worked in a health care facility during the previous $21 \mathrm{~d}$ during screenings at their airport of entry to the United States during November 5-December 1, 2014, and the exposure risk category assigned to them according to CDC's Interim US Guidance for Monitoring and Movement of Persons with Potential Ebola Virus Exposure $(4,6)$. The low estimate value of arrivals of HCWs $(30$ arriving HCWs) was approximately the lowest rate of high-risk and some-risk HCWs entering the United States. The high estimate value (60 arriving HCWs) was approximately the highest rate of high-, some-, and low-risk HCWs entering the United States (CDC, unpub. data).

fOutput 1 = (Input $1 /$ Input 2) $\times$ Input 3; Output 2 = Output $1+($ Output $1 \times$ Input 4). See online Technical Appendix 1 for further details.

$\S$ Assumed number of additional secondary transmissions occurring in the United States per primary case based on the range of experience from the outbreak: 1 imported case to the United States resulted in 2 secondary infections, and several case-patients have been treated without any secondary infections (7).

TNumber of medical evacuations was obtained from unpublished Medical Evacuation Missions Reports (US Department of Health and Human Services, unpub. data).

around the average estimate of arriving case-patients. The treatment length used in both the low and high estimate calculations was 14.8 days, calculated as a weighted average of the LOS of hospitalized case-patients treated in West Africa through September 2014 (online Technical Appendix 1 Table 5) (8). We conducted a sensitivity analysis using LOS and reduced case-fatality rate of patients treated in the United States (online Technical Appendix 1 Table 6).

For late 2014, the low estimate of the average number of beds needed to treat patients with Ebola at any point in time was $1(95 \%$ CI $0-3)$. The high estimate was 7 (95\% CI 2-13).

In late 2014, the United States had to plan and prepare to treat additional Ebola case-patients. By mid-January 2015, the capacity of Ebola treatment centers in the United States (49 hospitals with 71 total beds [9]) was sufficient to care for our highest estimated number of Ebola patients. Policymakers already have used the BED model to evaluate responses to the risk for arrival of Ebola virus-infected travelers, and it can be used in future infectious disease outbreaks of international origin to plan for persons requiring treatment within the United States.

\section{Acknowledgments}

We thank Caresse Campbell and Bishwa Adhikari for compiling various data and the Centers for Disease Control and Prevention's Ebola Response Global Migration Task Force for data on HCW arrivals.

\section{References}

1. Ashkenas J, Buchanan L, Burgess J, Fairfield H, Grady D, Keller J, et al. How many Ebola patients have been treated outside of Africa?: New York Times; 01/26/2015 [cited 2015 Feb 13]. http://www.nytimes.com/interactive/2014/07/31/world/africa/ ebola-virus-outbreak-qa.html

2. Gomes MFC, Piontti AP, Rossi L, Chao D, Longini I, Halloran ME, et al. Assessing the international spreading risk associated with the 2014 West African Ebola outbreak. PLoS Curr. 2014;6. pii: ecurrents.outbreaks.cd818f63d40e24aef769dda7df9e0da5. http://dx.doi.org/10.1371/currents.outbreaks.cd818f63d40 e24aef769dda7df9e0da5

3. Bogoch II, Creatore MI, Cetron MS, Brownstein JS, Pesik N, Miniota J, et al. Assessment of the potential for international dissemination of Ebola virus via commercial air travel during the 2014 west African outbreak. Lancet. 2015;385:29-35. http://dx.doi.org/10.1016/S0140-6736(14)61828-6.

4. Brown CM, Aranas AE, Benenson GA, Brunette G, Cetron M, Chen TH, et al. Airport exit and entry screening for EbolaAugust-November 10, 2014. MMWR Morb Mortal Wkly Rep. 2014;63:1163-7.

5. World Health Organization. Global Alert and Response (GAR). Situation reports with epidemiological data: archive. Situation report update-October 22, 2014. Ebola response roadmap situation report [cited 2014 Dec 24 ]. http://www.who.int/csr/ disease/ebola/situation-reports/archive/en/

6. Centers for Disease Control and Prevention. Interim US guidance for monitoring and movement of persons with potential Ebola virus exposure. December 24, 2014 [cited 2014 Dec 24]. http://www.cdc.gov/vhf/ebola/exposure/monitoring-andmovement-of-persons-with-exposure.html

7. Chevalier MS, Chung W, Smith J, Weil LM, Hughes SM, Joyner SN, et al. Ebola virus disease cluster in the United StatesDallas County, Texas, 2014. MMWR Morb Mortal Wkly Rep. 2014;63:1087-8..

8. World Health Organization Ebola Response Team. Ebola virus disease in West Africa - the first 9 months of the epidemic and 
forward projections. N Engl J Med. 2014;371:1481-95. Epub 2014 Sep 22. http://dx.doi.org/10.1056/NEJMoa1411100.

9. Centers for Disease Control and Prevention. Current Ebola treatment centers. 12/31/2014 [cited 2014 Jan 5]. http://www.cdc.gov/ vhf/ebola/healthcare-us/preparing/current-treatment-centers.html

Address for correspondence: Gabriel Rainisch, Centers for Disease Control and Prevention, 1600 Clifton Rd NE, Mailstop C18, Atlanta, GA 30333, USA; email: Grainisch@cdc.gov

\section{Highly Pathogenic Avian Influenza $A(H 5 N 1)$ Virus in Poultry, Nigeria, 2015}

\section{Isabella Monne, ${ }^{1}$ Clement Meseko, ${ }^{1}$ Tony Joannis, Ismaila Shittu, Mohammed Ahmed, Luca Tassoni, Alice Fusaro, Giovanni Cattoli}

\begin{abstract}
Author affiliations: Istituto Zooprofilattico Sperimentale delle Venezie, Padova, Italy (I. Monne, L. Tassoni, A. Fusaro,

G. Cattoli); National Veterinary Research Institute, Vom, Nigeria

(C. Meseko, T. Joannis, I. Shittu, M. Ahmed)
\end{abstract}

DOI: http://dx.doi.org/10.3201/eid2107.150421

To the Editor: In Nigeria, from February 2006 through July 2008, outbreaks of highly pathogenic avian influenza (HPAI) subtype H5N1 virus infection in poultry negatively affected animal and public health as well as the agricultural sector and trade. These outbreaks were caused by viruses belonging to genetic clades 2.2 and 2.2.1 (1). In January 2015, seven years after disappearance of the virus, clinical signs of HPAI (swollen head and wattles, hemorrhagic shank and feet) and increased mortality rates were observed among backyard poultry in Kano and in a live bird market in Lagos State, Nigeria. The virus was isolated from 2 samples independently collected from the poultry farm (parenchymatous tissues) and the market (tracheal swab), and H5 subtype virus was identified by reverse transcription PCR. The samples were adsorbed onto 2 Flinders Technology Associates cards (GE Healthcare Life Sciences, Little Chalfont, UK), which were sent to the World Organisation for Animal Health/Food and Agriculture Organization of the United Nations Reference Laboratory for Avian Influenza in Italy for subtype confirmation and genetic characterization. Influenza $\mathrm{A}(\mathrm{H} 5 \mathrm{~N} 1)$ virus was detected in both samples, and sequencing of the hemagglutinin (HA) gene showed that the viruses possessed the molecular markers for HPAI viruses with a multibasic amino acid cleavage site motif (PQRERRRKR*G).

The complete genome of the virus from backyard poultry was successfully sequenced from the genetic material

${ }^{1}$ These authors contributed equally to this article. extracted from the Flinders Technology Associates cards by using an Illumina MiSeq platform (2) and was submitted to the Global Initiative on Sharing All Influenza Data database (http://platform.gisaid.org/) under accession nos. EPI556504 and EPI567299-EPI567305. Maximum-likelihood trees were estimated for all 8 gene segments by using the best-fit general time reversible plus invariant sites plus gamma 4 model of nucleotide substitution with PhyML (3). The topology of the phylogenetic tree of the HA gene demonstrated that the H5N1 virus from Nigeria (A/chicken/Nigeria/15VIR339-2/2015) falls within genetic clade 2.3.2.1c (Figure, panel A). In particular, the HA gene sequence clustered with $\mathrm{H} 5$ viruses collected in China in 2013 and with an $\mathrm{H} 5 \mathrm{~N} 1$ virus (A/Alberta/01/2014) isolated from a Canada resident who had returned from China (similarity $99.3 \%-99.5 \%)(4)$.

The remaining 7 genes were closely related to genes of A/Alberta/01/2014(H5N1), although the 2 viruses differed by 32 aa (online Technical Appendix, http://wwwnc. cdc.gov/EID/article/21/7/15-0421-Techapp1.pdf). Just as for the virus from Canada (4), 7 of 8 gene segments of the virus from Nigeria clustered with HPAI A(H5N1) virus circulating in Vietnam and China, while the polymerase basic 2 gene segment (Figure, panel B) resulted from reassortment with viruses circulating in the same Asian countries but belonged to the H9N2 subtype. Differing from the strain from Canada (only 2 aa mutations compared with the 2.3.2.1c candidate vaccine strain; 5), the strain from Nigeria possesses 6 aa differences: 3 in HA1 and 3 in HA2 (online Technical Appendix). The effect of these mutations on the antigenic relatedness of these strains should be further explored.

Molecular characterization demonstrated that the polymerase basic 2 sequence contains glutamic acid at position 627 , establishing the lack of a well-known mammalian adaptation motif (6). Mutations associated with increased virulence in mice have been observed in the nonstructural protein 1 (P42S, D87E, L98F, I101M, and the 80-84 deletion) and in the matrix 1 proteins $(\mathrm{N} 30 \mathrm{D}, \mathrm{T} 215 \mathrm{~A})$. In addition, the substitutions D94N, S133A, S155N (H5 numbering) associated with increased binding to $\alpha-2,6$ sialic acid have been identified in the HA protein. However, most of these substitutions are present in the $\mathrm{H} 5 \mathrm{~N} 1$ virus sequences from Asia included in our phylogenetic analyses, suggesting that they may be common among the HPAI H5 virus subtype. Mutations associated with resistance to antiviral drugs have not been detected (7).

The results obtained from whole-genome analysis provide evidence that a novel clade of the $\mathrm{A}(\mathrm{H} 5 \mathrm{~N} 1)$ virus, specifically clade $2.3 .2 .1 \mathrm{c}$, has reached Nigeria. Although ascertaining how and exactly when this has happened is difficult, it seems most likely that the virus entered the country in December 2014, as evidenced by unverified 